\title{
An integrated approach identifies IFN-regulated microRNAs and targeted mRNAs modulated by different HCV replicon clones
}

\author{
Roberto Bruni ${ }^{1}$, Cinzia Marcantonio ${ }^{1}$, Elena Tritarelli ${ }^{1}$, Paola Tataseo ${ }^{2}$, Emilia Stellacci ${ }^{1,3}$, Angela Costantino ${ }^{1}$, \\ Umbertina Villano ${ }^{1}$, Angela Battistini ${ }^{1}$ and Anna Rita Ciccaglione ${ }^{1 *}$
}

\begin{abstract}
Background: Infections with hepatitis C virus (HCV) progress to chronic phase in $80 \%$ of patients. To date, the effect produced by HCV on the expression of microRNAs (miRs) involved in the interferon- $\beta$ (IFN- $\beta$ ) antiviral pathway has not been explored in details. Thus, we compared the expression profile of 24 selected miRs in IFN- $\beta$ treated Huh-7 cells and in three different clones of Huh-7 cells carrying a self-replicating HCV RNA which express all viral proteins (HCV replicon system).
\end{abstract}

Methods: The expression profile of 24 selected miRs in IFN- $\beta$-treated Huh-7 cells and in HCV replicon 21-5 clone with respect to Huh-7 parental cells was analysed by real-time PCR. To exclude clone specific variations, the level of 16 out of 24 miRs, found to be modulated in 21-5 clone, was evaluated in two other HCV replicon clones, 22-6 and 21-7. Prediction of target genes of 3 miRs, confirmed in all HCV clones, was performed by means of miRGator program. The gene dataset obtained from microarray analysis of HCV clones was farther used to validate target prediction.

Results: The expression profile revealed that 16 out of 24 miRs were modulated in HCV replicon clone 21-5. Analysis in HCV replicon clones 22-6 and 21-7 indicated that 3 out of 16 miRs, (miR-128a, miR-196a and miR-142$3 p$ ) were modulated in a concerted fashion in all three HCV clones. Microarray analysis revealed that 37 out of 1981 genes, predicted targets of the 3 miRs, showed an inverse expression relationship with the corresponding miR in HCV clones, as expected for true targets. Classification of the 37 genes by Panther System indicated that the dataset contains genes involved in biological processes that sustain HCV replication and/or in pathways potentially implicated in the control of antiviral response by HCV infection.

Conclusions: The present findings reveal that 3 IFN- $\beta$-regulated miRs and 37 genes, which are likely their functional targets, were commonly modulated by HCV in three replicon clones. The future use of miR inhibitors or mimics and/or siRNAs might be useful for the development of diagnostic and therapeutic strategies aimed at the recovering of protective innate responses in HCV infections.

\section{Background}

Infection with hepatitis $\mathrm{C}$ virus ( $\mathrm{HCV})$ represents the major cause of liver disease, affecting more than 170 million individuals worldwide. After a sub-clinical phase, greater than $80 \%$ of patients progress to persistent $\mathrm{HCV}$

\footnotetext{
* Correspondence: annarita.ciccaglione@iss.it

'Department of Infectious, Parasitic and Immunomediated Diseases, Istituto Superiore di Sanità, Rome, Italy

Full list of author information is available at the end of the article
}

infection, the leading cause of chronic liver disease associated with cirrhosis and hepatocellular carcinoma [1,2].

In the last years, microarray technology provided a comprehensive analysis of alterations in gene expression induced by $\mathrm{HCV}$ and revealed important processes of virus-host interactions [3-7]. Interestingly, microarray studies indicated that HCV stimulates the endogenous Type I Interferon (IFN- $\alpha / \beta)$ pathway as suggested by activation of IFN-stimulated genes (ISGs) [8-15]. Recently, it has been proposed that also microRNAs (miRs), a class of small

\section{Biomed Central}

(c) 2011 Bruni et al; licensee BioMed Central Ltd. This is an Open Access article distributed under the terms of the Creative Commons Attribution License (http://creativecommons.org/licenses/by/2.0), which permits unrestricted use, distribution, and reproduction in any medium, provided the original work is properly cited. 
non-coding regulatory RNAs, are involved in the antiviral pathway induced by IFN- $\beta$ treatment. The synthetic introduction of five IFN- $\beta$-induced miRs into HCV replicon cells may simulate the antiviral effect of IFN- $\beta$ blocking HCV replication and infection. These five miRs (miR-196, miR-296, miR-351, miR-431 and miR-448) likely induced an antiviral state either through alteration of gene expression and/or directly targeting HCV RNA, as was demonstrated for two of them (miR-196 and miR-448) [16].

Although $\mathrm{HCV}$ activates the endogenous IFN- $\alpha / \beta$ pathway it conversely shows an impressive ability to induce persistent infections. Indeed, it is also clear that $\mathrm{HCV}$ has evolved several mechanisms to control the IFN antiviral response, inhibiting the pathway at different levels [17]. Recently, it has been suggested that an improper pre-activation of ISGs in the liver of $\mathrm{HCV}$ infected patients may hinder the antiviral response. The discovery of a genetic polymorphism in the interleukin 28B (IL28B) region on chromosome 19 of HCV patients depicted a more complex virus-host interaction. The IL28B non-CC variant has been associated with nonresponse to the IFN therapy and with lower rates of spontaneous clearance of $\mathrm{HCV}$ infection. The poorresponse variant is also associated with higher intrahepatic expression level of ISGs [18-20].

A missing aspect in this scenario is the study of the effect produced by HCV on the expression of IFN- $\beta$ induced miRs. This is a relevant issue to understand how the virus can suppress the innate antiviral signaling and induce a persistent infection.

In a previous paper, we identified a common transcriptional response of Huh-7 cells to different clones of fulllength HCV replicon [21]. Although a more advanced $\mathrm{HCV}$ cell culture models that release HCV viral particles has been developed [22-24], the replicon system has the advantage of taking into account the cellular gene expression variability of different $\mathrm{HCV}$ replicon cell clones. This approach allows searching for modulated genes shared by all clones, which are likely to be strictly needed for viral replication in different cellular contexts.

On this basis, we used the replicon system to identify IFN-regulated miRs that are modulated by HCV RNA replication. In particular, we analyzed the expression profile of 24 selected miRs in IFN- $\beta$-treated Huh-7 cell line and in three cell clones carrying a full-length $\mathrm{HCV}$ replicon (clones 21-5, 22-6 and 21-7). Among the identified 16 miRs modulated in the 21-5 clone, 3 miRs showed concordant expression when analyzed in the two other HCV replicons. By a combined approach, based on bioinformatic prediction and microarray analysis, we also identified 37 genes, targeted by the 3 miRs, which are involved in pathways and biological processes potentially implicated in the control of antiviral response by $\mathrm{HCV}$ infection.

\section{Results}

Expression of IFN- $\beta$-regulated miRs in 21-5 HCV replicon cells and in IFN- $\beta$-treated Huh-7 cells

To determine the impact of HCV RNA replication and protein synthesis on IFN- $\beta$-regulated miRs, we compared the expression profile of selected miRs in 21-5 cells, harbouring a full-length HCV genome, and in IFN- $\beta$-treated Huh-7 cells with the Huh-7 parental cell line.

In particular, the list of assayed miRs includes (a) eight IFN- $\beta$-induced miRs, which displayed complementarity in their seed sequences with HCV RNA genome (miR-1, miR-30, miR-128, miR-196, miR-296, miR-351, miR-431, miR-448) [16], (b) two miRs reported as IFN- $\beta$-unresponsive miRs (miR-125 and miR-142) [16], (c) miR-122a that promotes HCV RNA replication [25] and (d) three miRs (miR-155, miR-146a and miR-146b) modulated in innate immune response in monocytes/macrophages $[26,27]$. Actually, the name of five of the above miRs (miR-30, miR-128, miR-196, miR-125 and miR-142) indicates miR families, not just individual mature miR species: thus, we analysed the level of each member of those families. Overall, the expression profile of 24 miRs in 215 and IFN- $\beta$-treated Huh- 7 cell lines was analysed (Table 1). Three miRs (miR-351, miR-431 and miR-448) showed an expression level below the detection limit of the assay $(\mathrm{Ct} \geq 40)$, while five miRs were not differentially expressed in 21-5 cells (miR-125b, miR-30e-5p, miR-30e-3p, miR$30 \mathrm{a}-5 \mathrm{p}, \mathrm{miR}-30 \mathrm{~d}$ : fold-change values $<1.2$ or $>-1.2$ in 21-5 cells). These eight miRs were not evaluated further.

The expression profile of the remaining $16 \mathrm{miRs}$ revealed that they were modulated by IFN- $\beta$ and/or $\mathrm{HCV}$ (Figure 1). In particular, concordant modulation (up- or down-regulation) of 9 miRs (miR-1, miR-30a-3p, miR142-5p, miR-142-3p, miR-146a, miR-146b, miR-155, miR-128a and miR-296) was observed in IFN- $\beta$-treated Huh-7 cells and in 21-5 replicon cells (Figure 1, panel A). This result indicates that HCV replication can induce a miR signature as IFN- $\beta$ treatment. Five miRs were modulated in 21-5 replicon cells only, as the level in IFN- $\beta$ treated Huh-7 cells was within the \pm 1.2 range set as background (Figure 1, panel B: miR-196b, miR-125a, miR-122a, miR-30c and miR-30b). Two miRs were modulated in an opposite manner in IFN- $\beta$-treated Huh7 cells and in 21-5 replicon cells (Figure 1, panel C: miR$128 \mathrm{~b}$ and $\mathrm{miR}-196 \mathrm{a})$.

\section{Identification of common miRs modulated in different $\mathrm{HCV}$ replicon clones}

To exclude that the miR expression profile was peculiar of the 21-5 clone, we analyzed the expression level of the 16 miRs in two other HCV replicon clones, 22-6 and 217. The analysis revealed that 3 miRs showed concordant modulation in $\mathrm{HCV}$ clones as compared to Huh-7 cells 
Table 1 Fold-change of 24 selected miRs in IFN $\beta$-treated Huh-7 and 21-5 cell lines vs. Huh-7

\begin{tabular}{|c|c|c|}
\hline & Huh-7+ IFN $\beta$ & 21-5 \\
\hline miR-1 & 30,13 & 22,11 \\
\hline miR-30a-3p & 4,46 & 8,79 \\
\hline miR-146a & 1,54 & 2,73 \\
\hline miR-142-5p & 2,83 & 2,20 \\
\hline miR-146b & 2,09 & 2,11 \\
\hline miR-142-3p & 2,09 & 1,74 \\
\hline miR-296 & $-1,47$ & $-1,40$ \\
\hline miR-155 & $-1,69$ & $-1,61$ \\
\hline miR-128a & $-1,47$ & $-1,88$ \\
\hline miR-128b & $-3,30$ & 2,09 \\
\hline miR-196a & 1,31 & $-1,50$ \\
\hline miR-125a & 1,05 & 3,43 \\
\hline miR-196b & 1,11 & 2,92 \\
\hline miR-30c & $-1,12$ & 1,30 \\
\hline miR-30b & $-1,04$ & 1,28 \\
\hline miR-122a & 1,14 & $-1,63$ \\
\hline miR-125b & $-1,10$ & 1,19 \\
\hline miR-30e-5p & 1,14 & 1,18 \\
\hline miR-30e-3p & $-2,12$ & 1,17 \\
\hline miR-30a-5p & $-1,38$ & 1,15 \\
\hline miR-30d & $-1,12$ & 1,02 \\
\hline miR-351 & n.d. & n.d. \\
\hline miR-431 & n.d. & n.d. \\
\hline miR-448 & n.d. & n.d. \\
\hline
\end{tabular}

In bold: fold-change values $>1.2$ or $<-1.2$

n.d.: not detected, i.e. miRs showing an expression level below the detection limit of the assay $(\mathrm{Ct} \geq 40)$

(Figure 2). In particular, miR-128a and miR-196a were down-regulated while miR-142-3p was up-regulated in all HCV clones.

\section{Identification of candidate miR target genes}

To predict target genes, which may be co-regulated by the 3 concordant miRs, we used miRGator, an on-line interface that uses multiple target prediction programs. It has been shown that, to date, no program is able to predict all experimentally confirmed target genes. Thus, to avoid as much as possible loss of putative target genes, relaxed options were used in miRGator [target genes predicted by at least one of the following programs: TargetScanS, miRanda and PicTar (4-way)]. After removal of multiple mRNAs corresponding to alternative mRNA transcripts from a single gene, individual gene lists were merged and a final list of 1981 total target genes was obtained, including genes controlled by at least one of the three miRs.

\section{Identification of genes common to miR target list and HCV microarray dataset}

The observation of an inverse relationship between levels of miRs and levels of their target mRNAs, due to
mRNA degradation of target genes, provides opportunities for validation of predicted targets using microarray profiling [28]. On this basis, to determine the candidate target genes directly regulated by miR-128a, miR-196a and miR-142-3p, we overlapped two datasets: the list of 1981 total target genes predicted for the 3 miRs (dataset 1) and a microarray dataset including 676 genes (725 probes) modulated in all HCV clones as compared to Huh-7 cells (dataset 2) reported in our previous study [21]. As shown in Figure 3, 83 genes were common to both datasets indicating that target genes of the 3 miRs account for 12, 3\% (83 out of 676) of the differentially expressed genes detected in all three $\mathrm{HCV}$ clones. The list of 83 genes, including relevant informations, is provided in Additional file 1, Table S1. As levels of most miRs and their target mRNAs exhibit an inverse expression relationship, we used gene expression profiling data to identify functional targets and validate target prediction, as previously reported [29]. By using this approach we found that 37 out of $83(44,5 \%)$ of the predicted target genes showed an expression level inversely correlated with that of the corresponding miR suggesting that, at least for these genes, a direct connection to miR regulation may be suggested. A complete list of the 37 genes (22 up-regulated and 15 down-regulated) and the corresponding $3 \mathrm{miRs}$ is provided in Table 2. The list includes symbol, name, probe ID, foldchange (FC) and p-value of the genes all obtained from microarray dataset. In addition, a functional description of the genes by Panther Protein Classification System is enclosed [30]. Overlapping the 37 genes with the dataset of genes resulting from microarray analysis of Huh-7.5 cells infected with HCV genotype 2a chimeric virus J6/ JFH [31] revealed 4 common genes (RND3, LTB4DH, RIOK3 and CHAF1B) which showed the same direction of regulation (i.e. up-regulated or down-regulated genes) in both HCV clones and J6/JFH microarray datasets supporting the biological relevance of these genes in $\mathrm{HCV}$ replicative cycle. Finally, to explore the involvement of the identified genes in HCV response to endogenous IFN, we also overlapped the list of 37 genes with the dataset of 1996 human genes annotated in the INTERFEROME database [32]. As shown in Table 2, four genes (HNMT, XPO1, PMPCB and HMGB1) were identified as Interferon Regulated Genes (IRGs).

\section{Biological functions of the miR target genes}

To classify genes into biological categories, we analyzed the Gene Ontology annotations of the 37 common genes with the Panther Protein Classification System [30]. As shown in Table 3, Panther System found several functional categories that were significantly enriched in this gene set compared to the entire NCBI reference list of human genome. We considered, as potentially 


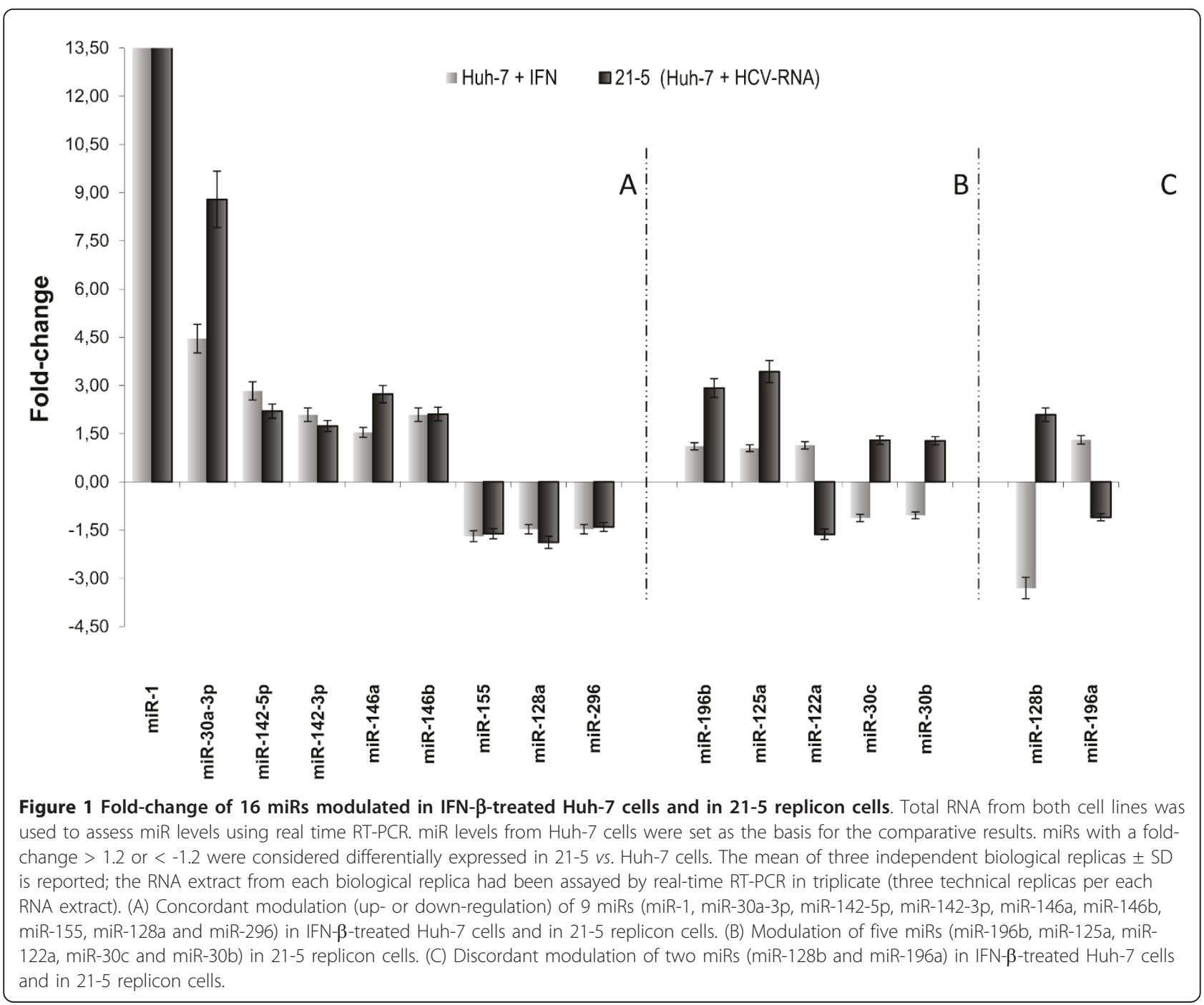

interesting, only categories showing a p-value $\leq 0.05$, as determined by the binomial statistic [33]. The 37 genes of the dataset were significantly classified by the Panther system in 6 biological processes (i.e., processes in which genes participate) and 3 molecular functions (i.e., biological functions of gene products). Compared with the NCBI reference list of human genome, this dataset showed a larger proportion of genes encoding proteins involved in chromatin binding and architecture, organelle organization, intracellular transport and neurotransmitter secretion (Table 3). In addition, genes associated with catalytic activity, enzyme regulator activity and chromatin binding were represented much more abundantly in the dataset. Interestingly, genes involved in the Ubiquitin proteasome pathway were also present in the dataset (Table 3). Additional file 2, Table S2 reports the complete list of the genes that are responsible for statistical enrichment of each category shown in Table 3

\section{Discussion}

In the present study we analyzed the effect of $\mathrm{HCV}$ replication on the expression of selected miRs involved in the IFN-pathway. In particular, we identified 3 miRs that are equally modulated by $\mathrm{HCV}$ in three $\mathrm{HCV}$ replicon clones and by IFN treatment. Moreover, we also identified 37 out of 83 predicted target genes, differentially expressed in HCV replicon cells, which are most likely functional targets of these 3 miRs: in fact they showed an inverse expression relationship with the level of the 3 miRs, as described for true targets. These genes could be implicated in regulation of the host response to $\mathrm{HCV}$.

About one half predicted targets did not show the expected inverse expression relationship with miR level, but this result is not surprising. First, computational prediction by miRgator was based on predictions from the widely used programs miRanda, TargetScanS and 


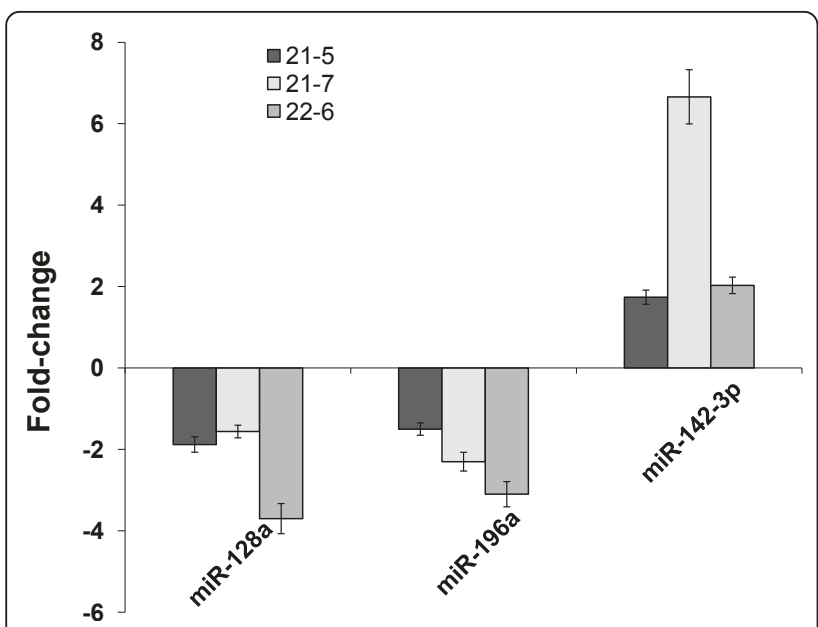

Figure 2 Concordant expression of 3 miRs in different HCV replicon clones. Total RNA from 21-5, 21-7 and 22-6 replicon cell lines was used to assess the level of miR-128a, miR-196a and miR143-3p, using real time RT-PCR. miR levels from Huh-7 cells were set as the basis for the comparative results. The mean of three independent experiments \pm SD is reported.

PicTar (see Materials and Methods). To date, these programs, as well as any other available prediction program, still have a very high false-positive rate, estimated to be up to $40 \%$ [34,35]: i.e. up to $40 \%$ genes predicted to be targeted by a miR are not, actually, true targets, and they will not show any inverse relationship. Second, each mRNA is usually targeted by multiple miRs and, in

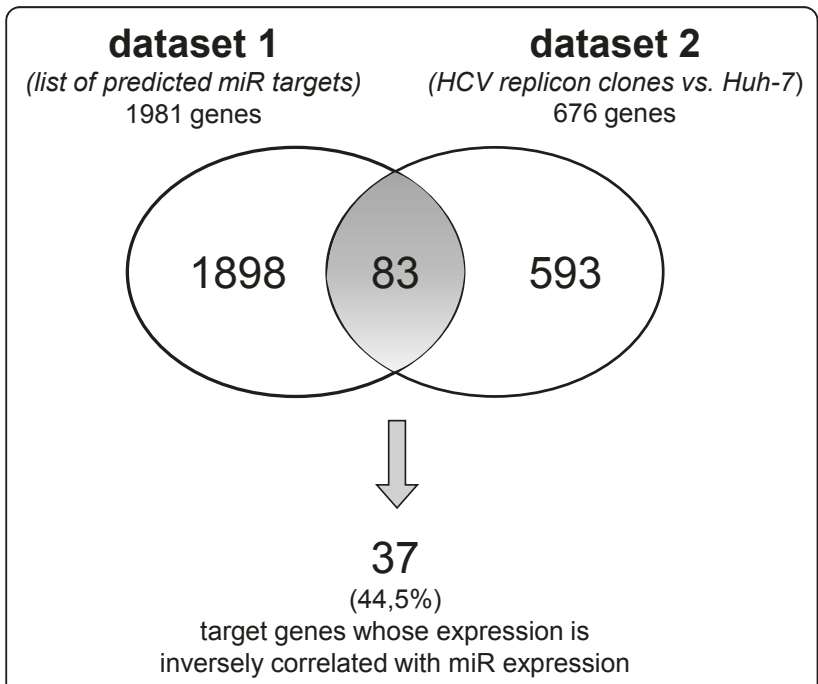

Figure 3 Venn diagram showing validation of predicted target genes by microarray analysis. Dataset 1 corresponds to the list of 1981 total target genes predicted for miR-128a, miR-196a and miR142-3p; dataset 2 includes 676 genes differentially expressed in microarray analysis in all HCV clones as compared to Huh-7 cells. The number of predicted target genes differentially expressed in microarray analysis was 83 , and $37(44,5 \%)$ showed an expression level inversely correlated with that of the corresponding miR. addition, each mRNA has its own set of modulating miRs. Whether or not a change in the level of a single miR can prevail on the effect of the other miRs simultaneously targeting the same mRNA in physiological conditions is, at present, poorly understood. However, it is possible in some cases it will produce no effect and, thus, even a true target will not show the expected inverse relationship.

The recent discovery of the roles of miRs in many human diseases suggests that studies exploring the relationship between HCV and miRs/mRNA may provide new insights into host cell response to HCV infection. Importantly, this approach also gives the opportunity to identify viral mechanisms that control the antiviral defense. Recently, it has been demonstrated that five IFN- $\beta$-modulated miRs (miR-196, miR-296, miR-351, miR-431 and miR-448) showed significant effect on HCV replication and at least two of them (miR-196 and miR448) are directly targeting the HCV genomic RNA [16]. Moreover, it seems that level of miR-122 is inversely correlated with the antiviral defense $[16,36,37]$.

Our expression analysis revealed that miR-196a was down-regulated in all three HCV replicon clones. Thus, at least for this component of the pathway, it seems that modulation of IFN-miRs may be altered by HCV in replicon cells. Interestingly, this miR targets the HCV RNA [16], thus, down-regulation of miR-196a may indirectly influence viral replication also by up-regulation of specific target genes. Accordingly, 11 genes, controlled by miR-196a, showed by microarray analysis an inverse expression relationship suggesting that they can be likely considered functional targets of miR-196a. Moreover, gene ontology analysis of the 11 genes highlights that some of them are really involved in pathways such as, extracellular matrix constitution (LAM4), oxidative stress (HADH2, LTB4DH) and cytoskeletal network (CENPE), which are relevant for HCV RNA replication $[7,38,39]$.

As for the IFN- $\beta$-regulated miR-296, miR-351, miR431, miR-448 and miR-122 (16) our data indicate that their expression in different HCV replicon clones is either not concordant (miR-296, and miR-122a) or not detected (miR-351, miR-431 and miR-448). In particular, miR-122a was down-regulated in 21-5 and 21-7 clones but its level was not modified in clone 22-6 (data not shown) while miR-296 was down-regulated in 21-5 clone and up-regulated in clone 22-6 and 21-7, respectively (data not shown). Moreover, miR 351, miR-431 and miR448 were not detected in all clones examined supporting, at least for miR-448, what found in human biopsies where miR-448 is totally absent [37].

Interestingly, we observed that two miRs, miR-142-3p and miR-128a, were up-regulated and down-regulated respectively by IFN- $\beta$ treatment of Huh-7 cells and in $\mathrm{HCV}$ replicon-expressing cells. Although modulation of 
Table 2 Reverse regulatory association of 3 differentially expressed miRNAs and their 37 predicted target genes in HCV replicon clones vs. Huh-7

\begin{tabular}{|c|c|c|c|c|c|c|}
\hline & Gene_Symbol & Gene_name & ProbelD & $\begin{array}{l}\text { Fold- } \\
\text { change }\end{array}$ & $\begin{array}{r}\mathrm{p}- \\
\text { value }\end{array}$ & Biological process and Molecular function \\
\hline \multicolumn{7}{|l|}{$\begin{array}{l}\text { Down-regulated } \\
\text { miR }\end{array}$} \\
\hline miR-128a & CAMTA1 & calmodulin binding transcription activator 1 & 164871 & 1.426 & 0.045 & Signal transduction/Calcium mediated signaling \\
\hline miR-128a & CAST & calpastatin & 222724 & 1.788 & 0.002 & Cysteine protease inhibitor|Select regulatory molecule \\
\hline miR-128a & CORO1C & coronin, actin binding protein, $1 \mathrm{C}$ & 107201 & 1.402 & 0.027 & Cytoskeletal protein|Actin binding cytoskeletal protein \\
\hline miR-128a & PARK7 & Parkinson disease (autosomal recessive, early onset) 7 & 136848 & 1.529 & 0.003 & Nucleic acid binding \\
\hline miR-128a & REPS1 & RALBP1 associated Eps domain containing 1 & 147893 & 1.352 & 0.002 & Intracellular protein traffic/Endocytosis \\
\hline miR-128a & $\mathrm{RND3}^{\#}$ & Rho family GTPase 3 & 129829 & 2.161 & 0.041 & G-protein|Small GTPase|Select regulatory molecule \\
\hline miR-128a & SAA4 & serum amyloid $\mathrm{A} 4$, constitutive & 214434 & 1.880 & 0.029 & Apolipoprotein;Defense/immunity protein \\
\hline miR-128a & TMCC1 & transmembrane and coiled-coil domain family 1 & 112169 & 1.369 & 0.031 & unclassified \\
\hline miR-128a & TRAPPC4 & trafficking protein particle complex 4 & 205369 & 1.502 & 0.012 & Membrane traffic protein \\
\hline miR-128a & UBE2E3 & $\begin{array}{l}\text { ubiquitin-conjugating enzyme E2E } 3 \text { (UBC4/5 homolog, } \\
\text { yeast) }\end{array}$ & 201108 & 1.505 & 0.030 & Ligase|Other ligase \\
\hline miR-128a & VAMP8 & vesicle-associated membrane protein 8 (endobrevin) & 226943 & 2.586 & 0.011 & SNARE protein|Membrane traffic protein \\
\hline miR-196a & ARMET & arginine-rich, mutated in early stage tumors & 144765 & 1.816 & 0.029 & unclassified \\
\hline miR-196a & $\mathrm{HADH} 2$ & hydroxyacyl-Coenzyme A dehydrogenase, type II & 142475 & 1.421 & 0.031 & Oxidoreductase|Reductase|Dehydrogenase;Oxidoreductase \\
\hline miR-196a & HIST1H2BD & histone $1, \mathrm{H} 2 \mathrm{bd}$ & 148940 & 2.656 & 0.020 & DNA binding \\
\hline miR-196a & $\mathrm{HNMT}^{\wedge}$ & histamine N-methyltransferase & 227509 & 1.423 & 0.039 & unclassified||RG \\
\hline miR-196a & LAMA4 & laminin, alpha 4 & 101059 & 2.660 & 0.033 & Extracellular matrix|Extracellular matrix linker protein \\
\hline miR-196a & LTB4DH $^{\#}$ & leukotriene B4 12-hydroxydehydrogenase & 210882 & 1.961 & 0.001 & Oxidoreductase|Reductase|Dehydrogenase;Oxidoreductase \\
\hline miR-196a & $\mathrm{PI3}$ & peptidase inhibitor 3, skin-derived (SKALP) & 128827 & 2.558 & 0.018 & Proteolysis|Protein metabolism and modification \\
\hline miR-196a & $\mathrm{RIOK}^{\#}$ & RIO kinase 3 (yeast) & 142169 & 3.226 & 0.018 & $\begin{array}{l}\text { Protein metabolism and modification|Protein } \\
\text { phosphorylation }\end{array}$ \\
\hline miR-196a & RRAGA & Ras-related GTP binding A & 105497 & 1.243 & 0.023 & G-protein|Small GTPase|Select regulatory molecule \\
\hline miR-196a & ZMYND11 & zinc finger, MYND domain containing 11 & 161540 & 1.665 & 0.036 & Transcription factor|Transcription cofactor \\
\hline miR-128a/miR-196a & $\mathrm{CENPE}^{\S}$ & centromere protein $\mathrm{E}, 312 \mathrm{kDa}$ & 165425 & 1.436 & 0.018 & Structural constituent of cytoskeleton \\
\hline \multicolumn{7}{|l|}{ Up-regulated miR } \\
\hline miR-142-3p & $\mathrm{ZCCHC14}$ & zinc finger, $\mathrm{CCHC}$ domain containing 14 & 200292 & 0.759 & 0.035 & unclassified \\
\hline miR-142-3p & $\mathrm{XPO}^{\wedge}$ & exportin 1 (CRM1 homolog, yeast) & 105030 & 0.748 & 0.002 & Intracellular protein transport||RG \\
\hline miR-142-3p & ATAD2 & ATPase family, AAA domain containing 2 & 114584 & 0.745 & 0.007 & Hydrolase activity \\
\hline miR-142-3p & TRIM33 & tripartite motif-containing 33 & 134526 & 0.714 & 0.004 & $\begin{array}{l}\text { Transcription cofactor;Nucleic acid binding|Transcription } \\
\text { factor }\end{array}$ \\
\hline miR-142-3p & RAB1A & RAB1A, member RAS oncogene family & 122650 & 0.704 & 0.045 & G-protein|Small GTPase|Select regulatory molecule \\
\hline miR-142-3p & TFG & TRK-fused gene & 210281 & 0.686 & 0.026 & unclassified \\
\hline miR-142-3p & $\mathrm{PMPCB}^{\wedge}$ & peptidase (mitochondrial processing) beta & 210046 & 0.684 & 0.015 & Oxidoreductase activity||RG \\
\hline miR-142-3p & ZNF226 & zinc finger protein 226 & 178824 & 0.682 & 0.043 & Zinc finger transcription factor \\
\hline miR-142-3p & ANKHD1 & ankyrin repeat and $\mathrm{KH}$ domain containing 1 & 224628 & 0.658 & 0.006 & unclassified \\
\hline miR-142-3p & CXADR & coxsackie virus and adenovirus receptor & 108284 & 0.620 & 0.025 & Other receptor|Receptor \\
\hline
\end{tabular}


Table 2 Reverse regulatory association of 3 differentially expressed miRNAs and their 37 predicted target genes in HCV replicon clones vs. Huh-7 (Continued)

\begin{tabular}{llllll}
\hline miR-142-3p & CHAF1B $^{\#}$ & chromatin assembly factor 1, subunit B (p60) & 174351 & 0.586 & 0.017 Nucleic acid binding|Chromatin/chromatin-binding protein \\
miR-142-3p & HMGB1 & high-mobility group box 1 & 151074 & 0.586 & 0.011 Proinflammatory cytokine||RG \\
miR-142-3p & BNIP3 & BCL2/adenovirus E1B 19kDa interacting protein 3 & 109165 & 0.551 & 0.000 unclassified \\
miR-142-3p & COG4 & component of oligomeric golgi complex 4 & 151150 & 0.394 & 0.042 Other RNA-binding protein|Nucleic acid binding \\
miR-142-3p & USH1C & Usher syndrome 1C (autosomal recessive, severe) & 195953 & 0.367 & 0.016 Cytoskeletal protein \\
\hline
\end{tabular}

${ }^{\S}$ Gene targeted by two down-regulated miRs

Interferon regulated gene (IRG) according to the INTERFEROME database

\# Gene showing same direction of regulation (up or down) in microarray analysis of HCV genotype 2a chimeric virus J6/JFH infection 
Table 3 Panther classification of Biological processes, Molecular functions and Pathways significantly enriched in the set of 37 genes

\begin{tabular}{|c|c|c|c|}
\hline & Observed Genes ${ }^{\circ}$ & Expected Genes“" & p-value $\cdots$ \\
\hline \multicolumn{4}{|l|}{ BIOLOGICAL PROCESS } \\
\hline \multicolumn{4}{|l|}{ Cellular process } \\
\hline Establishment or maintenance of chromatin architecture & 4 & 0.55 & $2.12 \mathrm{E}-03$ \\
\hline \multicolumn{4}{|l|}{ Cellular component organization } \\
\hline Organelle organization & 4 & 0.59 & $2.85 \mathrm{E}-03$ \\
\hline \multicolumn{4}{|l|}{ Transport } \\
\hline Intracellular protein transport & 9 & 2.98 & $2.16 \mathrm{E}-03$ \\
\hline Vesicle-mediated transport & 7 & 2.10 & 4.26E-03 \\
\hline Endocytosis & 4 & 1.04 & $1.96 \mathrm{E}-02$ \\
\hline \multicolumn{4}{|l|}{ System process } \\
\hline Neurotransmitter secretion & 3 & 0.63 & 2.45E-02 \\
\hline \multicolumn{4}{|l|}{ MOLECULAR FUNCTION } \\
\hline \multicolumn{4}{|l|}{ Catalytic activity } \\
\hline GTPase activity & 3 & 0.52 & $1.53 \mathrm{E}-02$ \\
\hline \multicolumn{4}{|l|}{ Enzyme regulator activity } \\
\hline Peptidase inhibitor activity & 2 & 0.32 & 4.08E-02 \\
\hline \multicolumn{4}{|l|}{ Binding } \\
\hline Chromatin binding & 2 & 0.34 & 4.59E-02 \\
\hline \multicolumn{4}{|l|}{ PATHWAYS } \\
\hline Ubiquitin proteasome pathway & 2 & 0.13 & 7.19E-03 \\
\hline
\end{tabular}

these 2 miRs by IFN- $\beta$ has never been described before, it is consistently observed in all clones suggesting that it may be part of the endogenous IFN response to HCV. The IFN pathway is a highly regulated process and several controls has been evolved to activate and turn off this pathway. In this scenario, the temporal modulation of specific miRs seems to represent one of the control elements [40]. It is important to note that this process cannot properly occur in cells sustaining HCV replication. In this case a chronic up or down-regulation of IFN-miRs, likely induced by the virus, may negatively affect the control of the pathway finally improving the efficacy of the antiviral effectors. It would be interesting to investigate whether the experimental use of miR inhibitors (for miR-142-3p) or miR mimics (for miR-128a) could influence the control of the endogenous IFN system.

Among the 37 predicted target genes showing an inverse expression relationship with the $3 \mathrm{miRs}$, four genes were identified as Interferon Regulated Genes (IRGs) according to the INTERFEROME database [32]. One of these genes (HNMT) is a predicted target gene of miR-196a while the other three (XPO1, PMPCB and HMGB1) are all targeted by miR-142-3p. Importantly, in autoimmune diseases the high mobility group box 1
(HMGB1) protein was identified as a component of immune complex-containing DNA or RNA, which may act as endogenous IFN- $\beta$ inducer [41]. Down-regulation of HMGB1 gene (fold change 0, 58; p-value 0,01 ) in all $\mathrm{HCV}$ replicon clones suggests that it might contribute to impair the activation of the IFN signaling. Currently, the role of these four IRGs in the IFN response to HCV replication is unknown. Thus, unraveling their contribution to the regulation of the IFN response may reveal new mechanisms of viral persistence.

Gene Ontology annotations of the 37 common genes also revealed the presence of two genes, UBE2E3 and ATAD2 targets of miR-128a and miR-142-3p respectively, which are involved in the Ubiquitin proteasome pathway. The contribution of this pathway to HCV subversion of the IFN response has never been investigated. This is a quite interesting issue as several viruses use the ubiquitin proteasome system to destabilize proteins, such as IRF3 and STAT proteins, that are important for transcription of Interferon and Interferon-stimulated genes [42].

In attempt to validate our data, we found that 4 out of 37 genes, targeted by the $3 \mathrm{miRs}$, were also modulated, in a concerted fashion, in HCV genotype 2 a chimeric virus J6/JFH microarray datasets [31] supporting the biological relevance of our results. In addition, 6 genes 
(4 up-regulated: CEACAM1, DDIT3, SCARB2, ZFAND2A; and 2 down-regulated: C9orf19 and RPL5) selected from the HCV clones microarray dataset were found to be modulated in a same way in liver biopsies of patients showing non-CC IL28B polymorphism [20]. This polymorphism is not a good predictor of response to IFN therapy and it is also associated with higher level of ISG expression in the liver and propension to chronicity. So, it can be speculated that modulation of IFN signature as mediated by common miRs in replicon cells, can mirror de-regulation of the IFN signaling proposed for such patients.

\section{Conclusions}

In the present study we used the HCV replicon system to identify IFN-regulated miRs that are modulated by HCV RNA replication. By a combined approach, based on Real-Time PCR, bioinformatic prediction and microarray analysis, we identified 3 IFN- $\beta$-regulated miRs and 37 genes, which are likely their functional targets, commonly modulated by $\mathrm{HCV}$ in three replicon clones. Gene ontology classified the 37 genes into functional categories potentially implicated in the control of antiviral response by $\mathrm{HCV}$ infection. The future design of siRNAs directed against some of these genes and the use of miRs and antimiRs may provide an experimental background for the development of therapeutic strategies aimed at the recovering of protective innate responses in $\mathrm{HCV}$ infections.

\section{Methods \\ Cell lines}

The Huh-7 cells carrying the Sfl HCV full-length replicon (genotype 1b) were obtained from Dr. R. Bartenschlager. The 21-5, 21-7 and 22-6 clones are cell lines that stably replicates the HCV replicon and were passaged as described [43-45]. HCV replicon cells were cultured in complete DMEM supplemented with 10\% FCS, antibiotics, $1 \times$ non-essential amino acids, and $250 \mu \mathrm{g} / \mathrm{ml}$ (21-5, 21-7) and $500 \mu \mathrm{g} / \mathrm{ml}(22-6)$ G418. Huh-7 cells were stimulated with $100 \mathrm{UI} / \mathrm{ml}$ IFN- $\beta$ for $16 \mathrm{~h}$.

\section{Quantitation of miRNAs}

Total RNA was extracted from $1 \times 10^{6}$ cells using miRNeasy mini kit (QIAGEN) according to manufacturer's instructions and quantified by Bioanalyzer 2100 (Agilent Technologies). TaqMan ${ }^{\circledR}$ MicroRNA Assays were used to quantitate miRs according to manifacturer's instructions (Applied Biosystems, Foster City, CA). A single TaqMan MicroRNA assay is used for each miR. All necessary primers and TaqMan probes are provided by the manufacturer with each assay, but details about sequence of primers and probes are not available (patented). Each TaqMan MicroRNA assay includes: (a) a "looped" primer, specific for each $\mathrm{miR}$, for the reverse transcription step (carried out with the TaqMan ${ }^{\circledR}$ MicroRNA Reverse Transcription Kit) and (b) a pair of "conventional" primers for amplification as well as a fluorescently labeled TaqMan probe for detection for the Real-Time amplification step (carried out with the TaqMan Universal PCR Master Mix).

In brief, 5 ng total RNA was reverse transcribed in $7.5 \mu \mathrm{l}$ reaction volume containing $50 \mathrm{nM}$ looped miR-specific primer, $1 \times \mathrm{RT}$ buffer, $0.25 \mathrm{mM}$ each dNTPs, $3.33 \mathrm{U} / \mu \mathrm{l}$ MultiScribe ${ }^{\mathrm{TM}}$ reverse transcriptase and $0.25 \mathrm{U} / \mu \mathrm{l}$ RNAse inhibitor. The reactions were incubated in an ABI Prism 7000 Sequence Detection System (Applied Biosystems) in a 96 -well plate for $30 \mathrm{~min}$ at $16^{\circ} \mathrm{C}, 30 \mathrm{~min}$ at $42^{\circ} \mathrm{C}$, followed by $5 \mathrm{~min}$ at $85^{\circ} \mathrm{C}$, and then held at $4^{\circ} \mathrm{C}$. Reverse transcription products were diluted three times with nuclease-free water prior to setting up PCR reactions. Each microRNA Real-Time PCR (10 $\mu$ l volume) was carried out in triplicate, and each $10 \mu \mathrm{l}$ reaction mixture included $2 \mu \mathrm{l}$ of diluted reverse transcription reaction product, $5 \mu \mathrm{l}$ of $2 \mathrm{X}$ TaqMan ${ }^{\circledR}$ Universal PCR Master Mix, 1X assay mix (including TaqMan ${ }^{\circledR}$ probe and forward and reverse primers). The reactions were incubated in an $\mathrm{ABI}$ Prism 7000 Sequence Detection System (Applied Biosystems) in 96 -well plates at $95^{\circ} \mathrm{C}$ for $10 \mathrm{~min}$, followed by 40 cycles of $95^{\circ} \mathrm{C}$ for $15 \mathrm{sec}$ and $60^{\circ} \mathrm{C}$ for $1 \mathrm{~min}$. Fold induction was calculated by $2^{-\Delta C t}$ method [46] using the level of Huh-7 cell line as a calibrator.

\section{Prediction of genes targeted by modulated miRs}

Putative gene targets of miRs found to be modulated in $\mathrm{HCV}$ clones were predicted by means of the miRGator program (available at http://genome.ewha.ac.kr/miRGator/miRNAexpression.html) that allows to combine gene predictions by TargetScanS, miRanda and PicTar softwares. To avoid loss of potential targets, a relaxed option was selected (retrieval of genes predicted by at least one program), so as to obtain for each miR a gene list as wide as possible.

\section{Gene network pathway analysis}

Gene Ontology (GO) annotations were analyzed with the Panther Protein Classification System [30] to identify functional annotations that were significantly enriched in this gene set compared to the entire human genome. Gene lists modulated by HCV were mapped onto biological pathways that were significantly represented.

\section{Additional material}

Additional file 1: Table S1. List of 83 genes resulting from overlapping (a) predicted target genes of miR-128a or miR-196a or miR-143-3p and (b) genes experimentally showing an expression change in HCV replicon clones vs. parental Hu-h7 cells by microarray analysis [21]. 
Additional file 2: Table S2. Individual genes in each of the classification groups found to be significantly enriched in the set of 37 genes by Panther.

\section{Acknowledgements and Funding}

The authors are grateful to Dr. Ralph Bartenschlager for the 21-5, 21-7 and 22-6 HCV replicon cell lines and Roberto Gilardi for careful artwork. This work was partially supported by the Institutional grants and by grants from the Italian AIDS project, by the Italian Ministry of Health and ISS-ACC program 3 to A.B.

\section{Author details}

'Department of Infectious, Parasitic and Immunomediated Diseases, Istituto Superiore di Sanità, Rome, Italy. ${ }^{2}$ ASL Avezzano-Sulmona, Transfusional Medicine and Molecular Biology Laboratory, Sulmona, Italy. ${ }^{3}$ Department of Hematology, Oncology and MolecularMedicine, Istituto Superiore di Sanità, Rome, Italy.

\section{Authors' contributions}

RB had been involved in conception and design of the study, data analysis and interpretation and revised the paper critically; CM and PT carried out real-time PCR assays, most of microarray experiments and contributed to data interpretation; ET and ES carried out cell culture experiments; AC and UV participated in data analysis; $A B$ contributed to the revision of the paper critically for important intellectual content; ARC had been involved in conception and design of the study, data analysis and interpretation and drafting the manuscript. All the authors had given final approval of the version to be published.

\section{Competing interests}

The authors declare that they have no competing interests.

Received: 5 April 2011 Accepted: 4 October 2011 Published: 4 October 2011

\section{References}

1. Hoofnagle JH: Hepatitis C: the clinical spectrum of disease. Hepatology 1997, 26:15S-20S.

2. Lauer GM, Walker BD: Hepatitis C virus infection. N Engl J Med 2001, 345:41-52, Review.

3. Walters KA, Syder AJ, Lederer SL, Diamond DL, Paeper B, Rice CM, Katze MG: Genomic analysis reveals a potential role for cell cycle perturbation in HCV-mediated apoptosis of cultured hepatocytes. PLOS Pathog 2009, 5:e1000269.

4. Walters KA, Joyce MA, Thompson JC, Smith MW, Yeh MM, Proll S, Zhu LF, Gao TJ, Kneteman NM, Tyrrell DL, Katze MG: Host-specific response to HCV infection in the chimeric SCID-beige/Alb-uPA mouse model: role of the innate antiviral immune response. PLoS Pathog 2006, 2:e59.

5. Walters KA, Smith MW, Pal S, Thompson JC, Thomas MJ, Yeh MM, Thomas DL, Fitzgibbon M, Proll S, Fausto N, Gretch DR, Carithers RL Jr, Shuhart MC, Katze MG: Identification of a specific gene expression pattern associated with $\mathrm{HCV}$-induced pathogenesis in HCV- and HCV/ HIV-infected individuals. Virology 2006, 350:453-64.

6. Smith MW, Walters KA, Korth MJ, Fitzgibbon M, Proll S, Thompson JC, Yeh MM, Shuhart MC, Furlong JC, Cox PP, Thomas DL, Phillips JD, Kushner JP, Fausto N, Carithers RL Jr, Katze MG: Gene expression patterns that correlate with hepatitis $C$ and early progression to fibrosis in liver transplant recipients. Gastroenterology 2006, 130:179-87.

7. Smith MW, Yue ZN, Korth MJ, Do HA, Boix L, Fausto N, Bruix J, Carithers RL Jr, Katze MG: Hepatitis $C$ virus and liver disease: global transcriptional profiling and identification of potential markers. Hepatology 2003, 38:1458-67.

8. Bigger CB, Guerra B, Brasky KM, Hubbard G, Beard MR, Luxon BA, Lemon SM, Lanford RE: Intrahepatic gene expression during chronic hepatitis C virus infection in chimpanzees. J Virol 2004, 78:13779-92.

9. Lanford RE, Guerra B, Bigger CB, Lee H, Chavez D, Brasky KM: Lack of response to exogenous interferon-alpha in the liver of chimpanzees chronically infected with hepatitis C virus. Hepatology 2007, 46:999-1008.
10. Lanford RE, Guerra B, Lee H, Chavez D, Brasky KM, Bigger CB: Genomic response to interferon-alpha in chimpanzees: implications of rapid downregulation for hepatitis C kinetics. Hepatology 2006, 43:961-72.

11. Su Al, Pezacki JP, Wodicka L, Brideau AD, Supekova L, Thimme R, Wieland S, Bukh J, Purcell RH, Schultz PG, Chisari FV: Genomic analysis of the host response to hepatitis C virus infection. Proc Natl Acad Sci USA 2002, 99:15669-74.

12. Bièche I, Asselah T, Laurendeau I, Vidaud D, Degot C, Paradis V, Bedossa P, Valla DC, Marcellin P, Vidaud M: Molecular profiling of early stage liver fibrosis in patients with chronic hepatitis C virus infection. Virology 2005, 332:130-44.

13. Lau DT, Fish PM, Sinha M, Owen DM, Lemon SM, Gale M Jr: Interferon regulatory factor-3 activation, hepatic interferon-stimulated gene expression, and immune cell infiltration in hepatitis $C$ virus patients. Hepatology 2008, 47:799-809.

14. Lau DT, Luxon BA, Xiao SY, Beard MR, Lemon SM: Intrahepatic gene expression profiles and alpha-smooth muscle actin patterns in hepatitis C virus induced fibrosis. Hepatology 2005, 42:273-81.

15. Helbig KJ, Lau DT, Semendric L, Harley HA, Beard MR: Analysis of ISG expression in chronic hepatitis $C$ identifies viperin as a potential antiviral effector. Hepatology 2005, 42:702-10.

16. Pedersen IM, Cheng G, Wieland S, Volinia S, Croce CM, Chisari FV, David M: Interferon modulation of cellular microRNAs as an antiviral mechanism. Nature 2007, 449:919-22.

17. Gale M Jr, Foy EM: Evasion of intracellular host defence by hepatitis $C$ virus. Nature 2005, 436:939-45, Review. Erratum in: Nature. 2005 Sep 8;437(7056):290.

18. Ge D, Fellay J, Thompson AJ, Simon JS, Shianna KV, Urban TJ, Heinzen EL, Qiu P, Bertelsen AH, Muir AJ, Sulkowski M, McHutchison JG, Goldstein DB: Genetic variation in IL28B predicts hepatitis $C$ treatment-induced viral clearance. Nature 2009, 461:399-401.

19. Thomas DL, Thio CL, Martin MP, Qi Y, Ge D, O'Huigin C, Kidd J, Kidd K, Khakoo SI, Alexander G, Goedert JJ, Kirk GD, Donfield SM, Rosen HR, Tobler LH, Busch MP, McHutchison JG, Goldstein DB, Carrington M: Genetic variation in IL28B and spontaneous clearance of hepatitis C virus. Nature 2009, 461:798-801.

20. Urban TJ, Thompson AJ, Bradrick SS, Fellay J, Schuppan D, Cronin KD, Hong L, McKenzie A, Patel K, Shianna KV, McHutchison JG, Goldstein DB, Afdhal N: IL28B genotype is associated with differential expression of intrahepatic interferon-stimulated genes in patients with chronic hepatitis C. Hepatology 2010, 52:1888-96.

21. Ciccaglione AR, Marcantonio C, Tritarelli E, Ferraris A, Tataseo P, Bruni R, Dallapiccola B, Gerosolimo G, Costantino A, Rapicetta M: Microarray analysis identifies a common set of cellular genes modulated by different HCV replicon clones. BMC Genomics 2008, 9:309.

22. Wakita T, Pietschmann T, Kato T, Date T, Miyamoto M, Zhao Z, Murthy K Habermann A, Krausslich HG, Mizokami M, Bartenschlager R, Liang TJ: Production of infectious hepatitis $\mathrm{C}$ virus in tissue culture from a cloned viral genome. Nat Med 2005, 11:791-796.

23. Zhong J, Gastaminza P, Cheng G, Kapadia S, Kato T, Burton DR, Wieland SF, Uprichard SL, Wakita T, Chisari FV: Robust hepatitis C virus infection in vitro. Proc Natl Acad Sci USA 2005, 102:9294-9299.

24. Lindenbach BD, Evans MJ, Syder AJ, Wölk B, Tellinghuisen TL, Liu CC, Maruyama T, Burton DR, McKeating JA, Rice CM: Complete replication of hepatitis C virus in cell culture. Science 2005, 309:623-6.

25. Jopling CL, Yi M, Lancaster AM, Lemon SM, Sarnow P: Modulation of hepatitis $C$ virus RNA abundance by a liver-specific microRNA. Science 2005, 309:1577-1581.

26. O'Connell RM, Taganov KD, Boldin MP, Cheng G, Baltimore D: MicroRNA155 is induced during the macrophage inflammatory response. Proc Natl Acad Sci USA 2007, 104:1604-9.

27. Taganov KD, Boldin MP, Chang KJ, Baltimore D: NF-kappaB-dependent induction of microRNA miR-146, an inhibitor targeted to signaling proteins of innate immune responses. Proc Natl Acad Sci USA 2006, 103:12481-6

28. Peng $X, L i Y$, Walters KA, Rosenzweig ER, Lederer SL, Aicher LD, Proll S, Katze MG: Computational identification of hepatitis $C$ virus associated microRNA-mRNA regulatory modules in human livers. BMC Genomic 2009, 10:373.

29. Huang JC, Babak T, Corson TW, Chua G, Khan S, Gallie BL, Hughes TR, Blencowe BJ, Frey BJ, Morris QD: Using expression profiling data to identify human microRNA targets. Nat Methods 2007, 4:1045-1049. 
30. Mi H, Lazareva-Ulitsky B, Loo R, Kejariwal A, Vandergriff J, Rabkin S, Guo N, Muruganujan A, Doremieux O, Campbell MJ, Kitano H, Thomas PD: The PANTHER database of protein families, subfamilies, functions and pathways. Nucleic Acids Res 2005, 33:D284-8.

31. Walters KA, Syder AJ, Lederer SL, Diamond DL, Paeper B, Rice CM, Katze MG: Genomic analysis reveals a potential role for cell cycle perturbation in HCV-mediated apoptosis of cultured hepatocytes. PLoS Pathog 2009, 5:e1000269.

32. Samarajiwa SA, Forster $S$, Auchettl K, Hertzog PG: INTERFEROME: the database of interferon regulated genes. Nucleic Acids Research 2009, , 37 Database: D852-7.

33. Cho RJ, Campbell MJ: Transcription, genomes, function. Trends Genet 2000, 16:409-415, Review.

34. Sethupathy P, Megraw M, Hatzigeorgiou AG: A guide through present computational approaches for the identification of mammalian microRNA targets. Nat Methods 2006, 3:881-886.

35. Martin G, Schouest K, Kovvuru P, Spillane C: Prediction and validation of microRNA targets in animal genomes. J Biosci 2007, 32(6):1049-1052.

36. Sarasin-Filipowicz M, Oakeley EJ, Duong FH, Christen V, Terracciano L, Filipowicz W, Heim MH: Interferon signaling and treatment outcome in chronic hepatitis C. Proc Natl Acad Sci USA 2008, 105:7034-9.

37. Sarasin-Filipowicz M, Krol J, Markiewicz I, Heim MH, Filipowicz W: Decreased levels of microRNA miR-122 in individuals with hepatitis $C$ responding poorly to interferon therapy. Nat Med 2009, 15:31-3.

38. Bost AG, Venable D, Liu L, Heinz BA: Cytoskeletal requirements for hepatitis C virus (HCV) RNA synthesis in the HCV replicon cell culture system. J Virol 2003, 77:4401-4408.

39. Korenaga M, Wang T, Li Y, Showalter LA, Chan T, Sun J, Weinman SA: Hepatitis $C$ virus core protein inhibits mitochondrial electron transport and increases reactive oxygen species (ROS) production. J Biol Chem 2005, 280:37481-37488.

40. Witwer KW, Sisk JM, Gama L, Clements JE: MicroRNA regulation of IFNbeta protein expression: rapid and sensitive modulation of the innate immune response. J Immunol 2010, 184:2369-76.

41. Finke $\mathrm{D}$, Eloranta $M L$, Rönnblom L: Endogenous type I interferon inducers in autoimmune diseases. Autoimmunity 2009, 42:349-52, Review.

42. Mclnerney GM, Karlsson Hedestam GB: Direct cleavage, proteasomal degradation and sequestration: three mechanisms of viral subversion of type I interferon responses. J Innate Immun 2009, 1:599-606, Review.

43. Frese M, Schwarzle V, Barth K, Krieger N, Lohmann V, Mihm S, Haller O, Bartenschlager R: Interferon-gamma inhibits replication of subgenomic and genomic hepatitis C virus RNAs. Hepatology 2002, 35:694-703.

44. Pietschmann T, Lohmann V, Kaul A, Krieger N, Rinck G, Rutter G, Strand D, Bartenschlager R: Persistent and transient replication of full-length hepatitis C virus genomes in cell culture. J Virol 2002, 76:4008-4021.

45. Ciccaglione AR, Stellacci E, Marcantonio C, Muto V, Equestre M, Marsili G, Rapicetta M, Battistini A: Repression of interferon regulatory factor 1 by hepatitis $C$ virus core protein results in inhibition of antiviral and immunomodulatory genes. J Virol 2007, 81:202-214.

46. Schmittgen TD, Livak KJ: Analyzing real-time PCR data by the comparative C(T) method. Nat Protoc 2008, 3:1101-1108

doi:10.1186/1471-2164-12-485

Cite this article as: Bruni et al: An integrated approach identifies IFNregulated microRNAs and targeted mRNAs modulated by different HCV replicon clones. BMC Genomics 2011 12:485.

\section{Submit your next manuscript to BioMed Central and take full advantage of:}

- Convenient online submission

- Thorough peer review

- No space constraints or color figure charges

- Immediate publication on acceptance

- Inclusion in PubMed, CAS, Scopus and Google Scholar

- Research which is freely available for redistribution

Submit your manuscript at www.biomedcentral.com/submit 